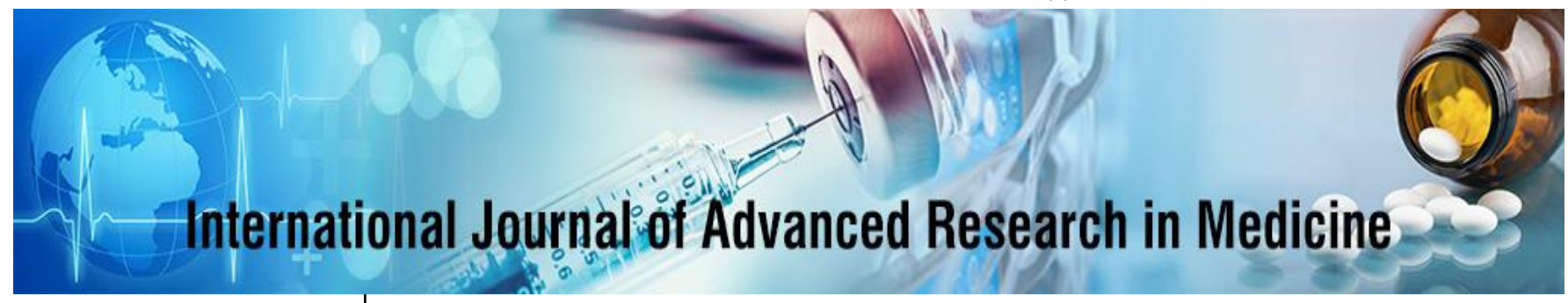

E-ISSN: 2706-9575

P-ISSN: 2706-9567

IJARM 2020; 2(2): 173-179

www.medicinepaper.net

Received: 15-05-2020

Accepted: 17-06-2020

Nishanam Gururaj

Associate Professor:

Department Of General

Medicine: Kakatiya Medical

College, Warangal

Telangana, India

Pillalamarri Purnima

Post Graduate, Department Of

General Medicine: Kakatiya

Medical College, Warangal

Telangana, India
Corresponding Author: Pillalamarri Purnima Post Graduate, Department Of General Medicine: Kakatiya Medical College, Warangal Telangana, India

\section{To evaluate and standardize the method of spot urine protein creatinine ratio for estimation of proteinuria}

\author{
Nishanam Gururaj and Pillalamarri Purnima
}

DOI: $\underline{\text { https://doi.org/10.22271/27069567.2020.v2.i2c.65 }}$

\begin{abstract}
Background: Proteinuria is an independent risk factor for diabetic nephropathy and a predictor of endstage renal disease. Measurement of protein excretion in a $24 \mathrm{hr}$ urine collection is the gold standard for the quantitative evaluation of proteinuria in diabetes. However, this is cumbersome, subjective to collection errors and required good compliance.

Aims: To evaluate and standardize the method of spot urine protein creatinine ratio for estimation of Proteinuria.

Materials and methods: We compared $24 \mathrm{hr}$ urine protein estimation with urine spot protein creatinine ratio in type 2 diabetes mellitus patients with proteinuria.

Results: In our study of 73 patients with type 2 diabetes mellitus and proteinuria, it was found that A maximum number of patients were noted in the age group 41-50 years. Males were more than females in the ratio of 2.04:1. The majority of patients had a duration of diabetes between $5-10$ yrs $(52.05 \%)$. The mean duration of diabetes was $9.24+/-6.1 \mathrm{yrs}$. Twenty-five patients $(34.25 \%)$ had nephrotic range proteinuria. There was a good correlation between urine PCR and $24 \mathrm{hr}$ urine protein at different levels of GFR. Maximum correlation between urine PCR and $24 \mathrm{hr}$ urine protein was seen in the GFR >60 group. There was a good correlation between urine PCR and $24 \mathrm{hr}$ urine protein at different ranges of proteinuria. A maximum correlation between urine PCR and $24 \mathrm{hr}$ urine was seen in the proteinuria group $<300$. There was a good correlation between urine PCR and serum creatinine. No statistically significant correlation was found between HBA1C levels and degree of proteinuria.

Conclusion: Urine protein creatinine ratio can be used as a faster diagnostic substitute for $24 \mathrm{hr}$ urine protein estimation in the screening and evaluation of diabetic nephropathy.
\end{abstract}

Keywords: Proteinuria, glomerular filtration rate (GFR), diabetic nephropathy.

\section{Introduction}

Proteinuria is an independent risk factor for renal diseases and a predictor of end- stage renal disease (ESRD). Accurate identification and quantification of proteinuria are of prime importance in the diagnosis and management of chronic renal disease. An increased proteinuria is associated with an increased risk of progressive renal failure and is used as both diagnostic and prognostic values in detection and confirmation of renal diseases or response to therapy ${ }^{[1,2]}$.

Diabetic nephropathy accounts for about $20 \%$ of cases of chronic renal failure and is the single most common cause of ESRD in many countries ${ }^{[3]}$. Diabetic kidney disease (DKD) is a life-threatening and irreversible microvascular complication characterized by the presence of persistent proteinuria, hypertension and progressive decline in renal function. It predisposes to excess morbidity and mortality resulting from renal failure and cardiovascular disease.

Early identification of patients at high risk for diabetic nephropathy (DN) is important to intensify the treatment and modify associated risk factors. Measurement of protein excretion in a $24 \mathrm{hr}$ urine collection is the gold standard for the quantitative evaluation of proteinuria. However, this method is inconvenient, since it is difficult to collect a complete $24 \mathrm{hr}$ urine sample accurately especially in an outpatient setting. An alternative method for quantitative evaluation of proteinuria is a measurement of protein to creatinine ratio in a spot urine sample which provides a convenient method to assess protein excretion. The spot urine protein creatinine ratio can be used as a surrogate and faster diagnostic substitute for 24-hour urine protein estimation in the screening and evaluation of diabetic nephropathy. 


\section{Materials and Methods}

The present Cross-sectional study is conducted in Kakatiya Medical College, Warangal from 2017-2019. Total 73 patients of confirmed Type 2 Diabetes Mellitus were included in study.

Inclusion Criteria: both genders of confirmed Type 2 Diabetes Mellitus patients, age $>40$ yrears.

Exclusion Criteria: Patients with Acute febrile illness, Urinary tract infections and excretion of abnormal amount of leucocytes in urine $>5$ leucocytes/ high power field, Chronic renal failure, Hypertensives, Glomerulonephritis due to other systemic conditions o Hematuria and Pregnant women.

A random sample of male and female patients with type 2 diabetes mellitus, satisfying the inclusion and exclusion criteria were selected. Data was collected with the aid of a proforma, which included patient history, clinical parameters like duration of diabetes, the prevalence of diabetic retinopathy and biochemical parameters like serum creatinine, eGFR, glycated hemoglobin, urine protein creatinine ratio and $24 \mathrm{hr}$ urine protein.

On the test day, in the morning at the start of the collection period (6.00 a.m.) patients were asked to void urine and discard this sample (as it contains the overnight urine present in the bladder). Subsequently, urine was collected for the next $24 \mathrm{hrs}$.

The last sample was to be collected on the next day at 6.00 a.m. A random sample was also collected on the day of the deposition of $24 \mathrm{hr}$ sample (the test day). Urine protein was estimated using the Pyrogallol red molybdate method and urine creatinine by modified Jaffe's method. Creatinine clearance was calculated using the MDRD (Modified Diet in Renal Disease) equation: GFR $(\mathrm{mL} / \mathrm{min} / 1.73 \mathrm{~m} 2)=175 \times$ $($ Scr $)-1.154 \times($ Age $)-0.203 \times(0.742$ if female $) \times(1.212$ if African American)

\section{Statistical Analysis}

Findings in the patients studied were evaluated and tabulated using Microsoft Excel and have been given as Annexure. Statistical analyses were conducted using SPSS 16.0 for Windows (SPSS Inc, Chicago, USA). Spearman's correlation coefficient was used for correlation of numerical variables. Kruskal Wallis test was used for the association between retinopathy and urine PCR.

\section{Results}

This study included 73 patients with type 2 diabetes mellitus who got admitted to the Department of Internal Medicine, Mahatma Gandhi Memorial Hospital, Warangal.

\section{Patient Characteristics}

The age of the patients studied ranged from 30 years to 80 years. The mean age of the patients was $51.9+/-10.4$ yrs. The mean age of female and male patients was $51.2+/-10.4$ yrs and $52.37+/-10.5$ respectively.

The maximum number of patients was noted in the age group 41-50 years i.e., $26(35.1 \%)$ and least in the age group 20-30 years i.e., 1 ( $1.35 \%)$. Of the 73 patients studied, 49 $(67.1 \%)$ patients were males and $24(32.9 \%)$, patients were females.

Table 1: Frequency distribution based on degree of proteinuria

\begin{tabular}{|c|c|c|}
\hline Degree of Proteinuria $\mathbf{( m g / 2 4 h r )}$ & Percentage & No. of patients \\
\hline$<300$ & $4.11 \%$ & 3 \\
\hline $300-3500$ & $61.64 \%$ & 45 \\
\hline$>3500 \quad$ Creatinine clearance(ml/min1/1.73m-2) & 25 \\
\hline \multicolumn{2}{|c|}{$\mid 26 \%$} \\
\hline $15-30$ & $27.03 \%$ & 19 \\
\hline $30-60$ & $34.24 \%$ & 19 \\
\hline$>60$ & $13.70 \%$ & 25 \\
\hline
\end{tabular}

Out of the 73 patients with proteinuria, 25 patients $(34.25 \%)$ had proteinuria of more than 3.5 gms $/ 24$ hours and 48 patients $(65.75 \%)$ had proteinuria of less than $3.5 \mathrm{gms} / 24$ hours.
Majority of patients had creatinine clearance (calculated by MDRD equation) between 30-60 ml/min1/ 1.73m-2 - 25 patients $(34.24 \%)$.

Table 2: Frequency distribution based on duration of diabetes

\begin{tabular}{|c|c|c|}
\hline Duration of diabetes (yrs) & Percentage & No. of patients \\
\hline$<5$ & $19.18 \%$ & 3 \\
\hline $5-10$ & $52.05 \%$ & 38 \\
\hline $10-15$ & $17.81 \%$ & 13 \\
\hline $15-20$ & $4.11 \%$ & 3 \\
\hline$>20$ & $6.85 \%$ & 5 \\
\hline
\end{tabular}

In our study, the majority of patients had a duration of diabetes between 5 to $10 \mathrm{yrs}-38$ patients $(52.05 \%)$.
The mean duration of diabetes was $9.24+/-6.1$ yrs. 


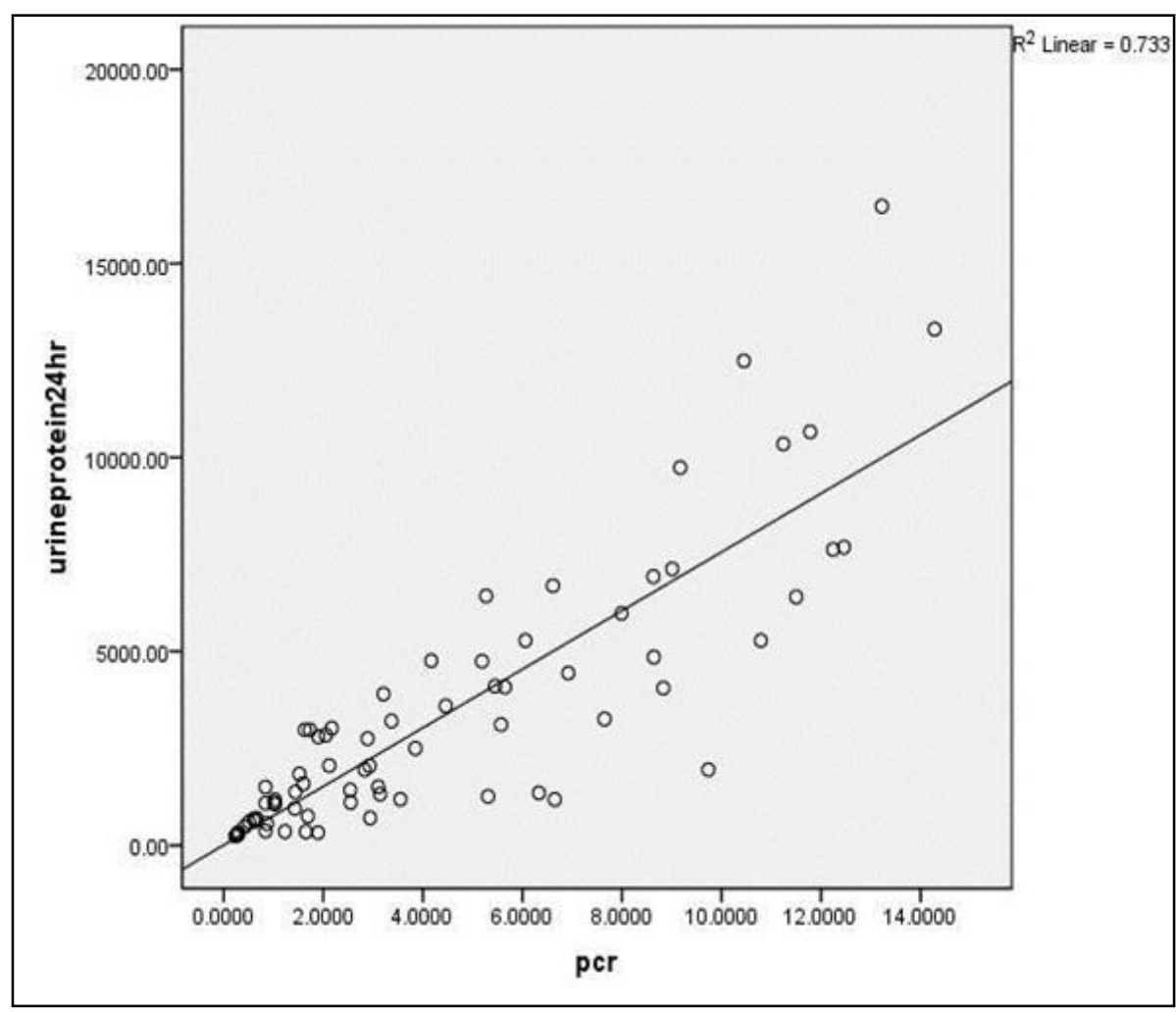

Fig 1: Correlation between urine pcr and $24 \mathrm{hr}$ urine protein

There was a significant positive correlation between urine

PCR and $24 \mathrm{hr}$ urine protein in our study $(\mathrm{r}=0.87 \mathrm{p}<0.001)$.

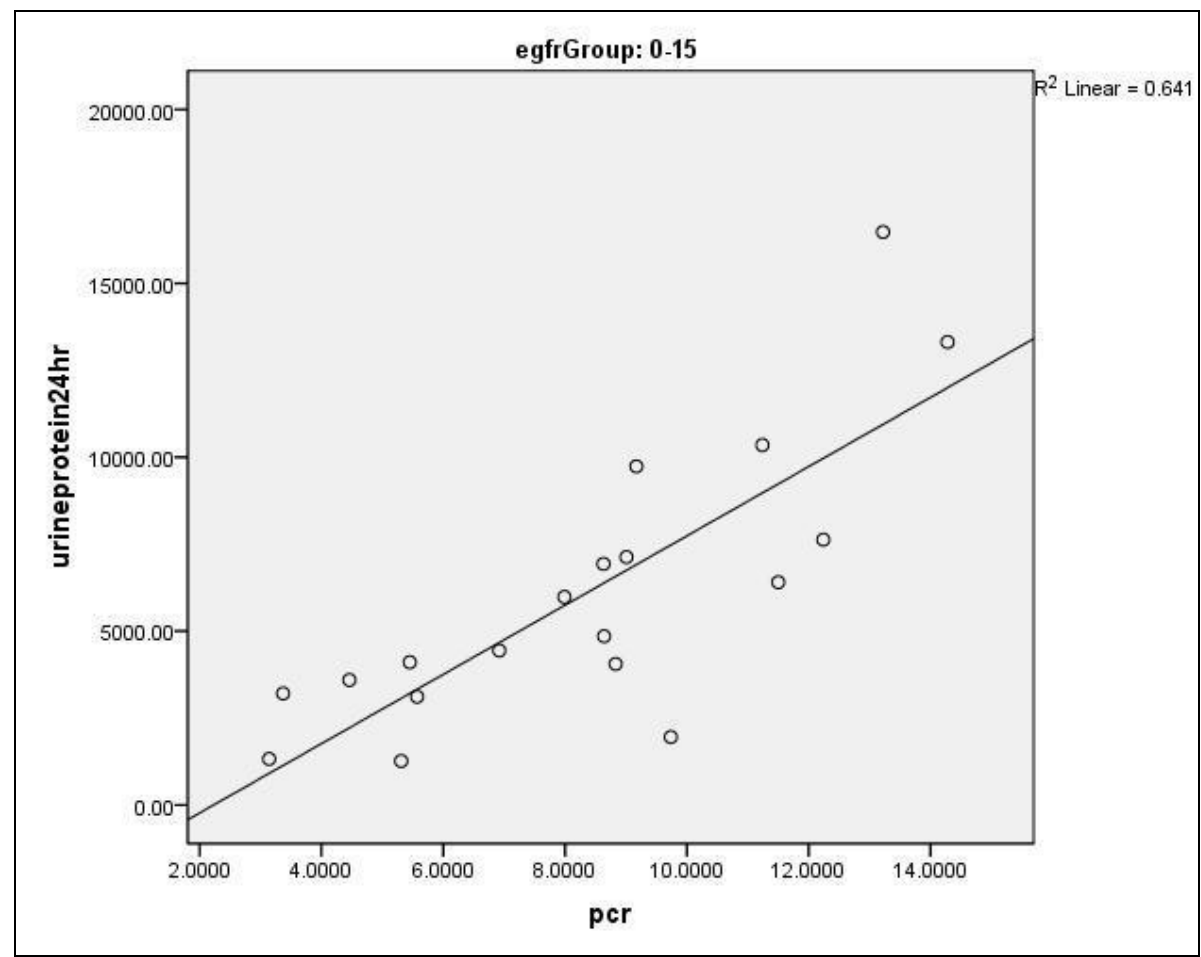

Fig 2: Correlation between urine PCR and $24 \mathrm{hr}$ urine protein at different levels of GFR(0-15) 


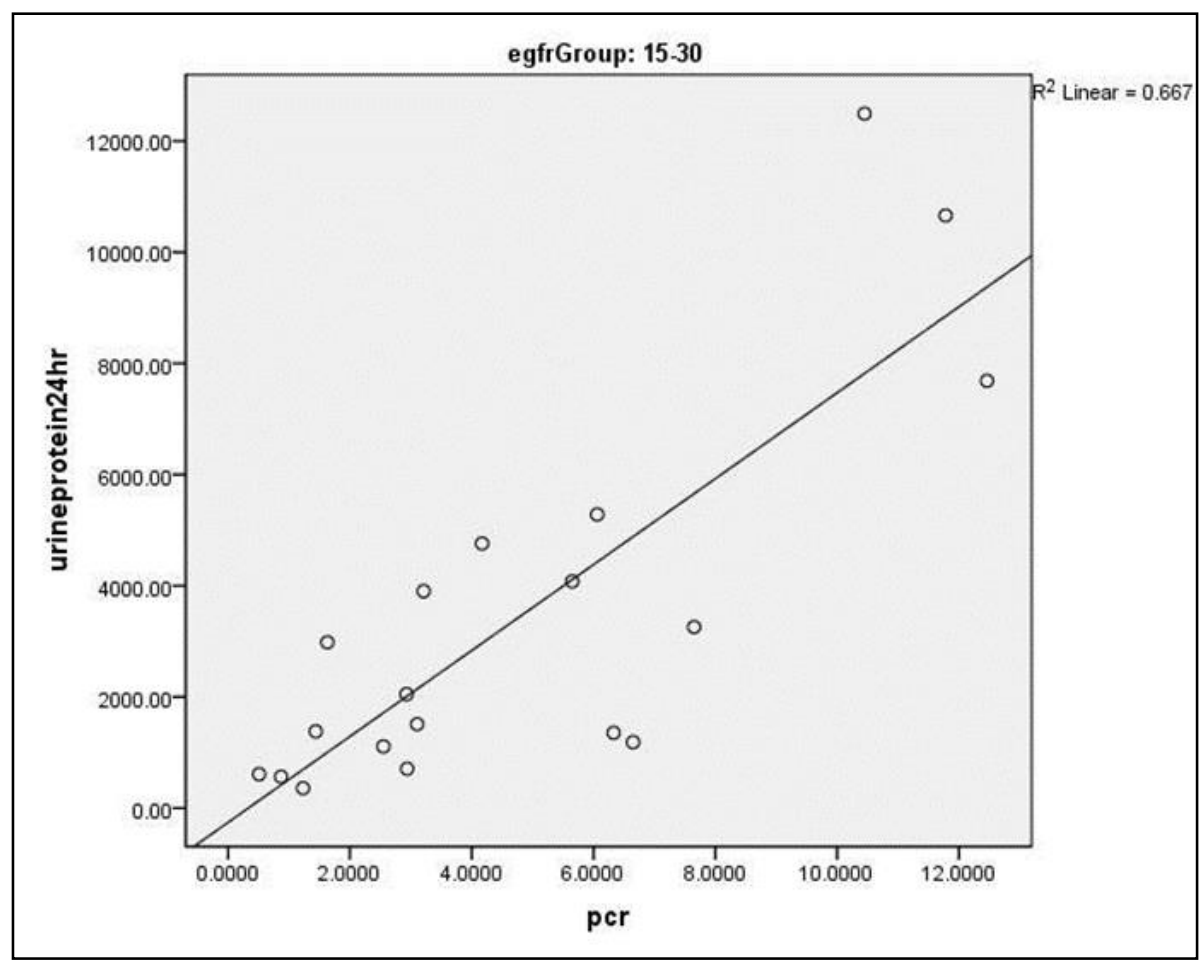

Correlation coefficient (r): $0.756 \mathrm{P}$ value: $<0.001$

Fig 3: Correlation between urine PCR and $24 \mathrm{hr}$ urine protein (eGFR 15-30)

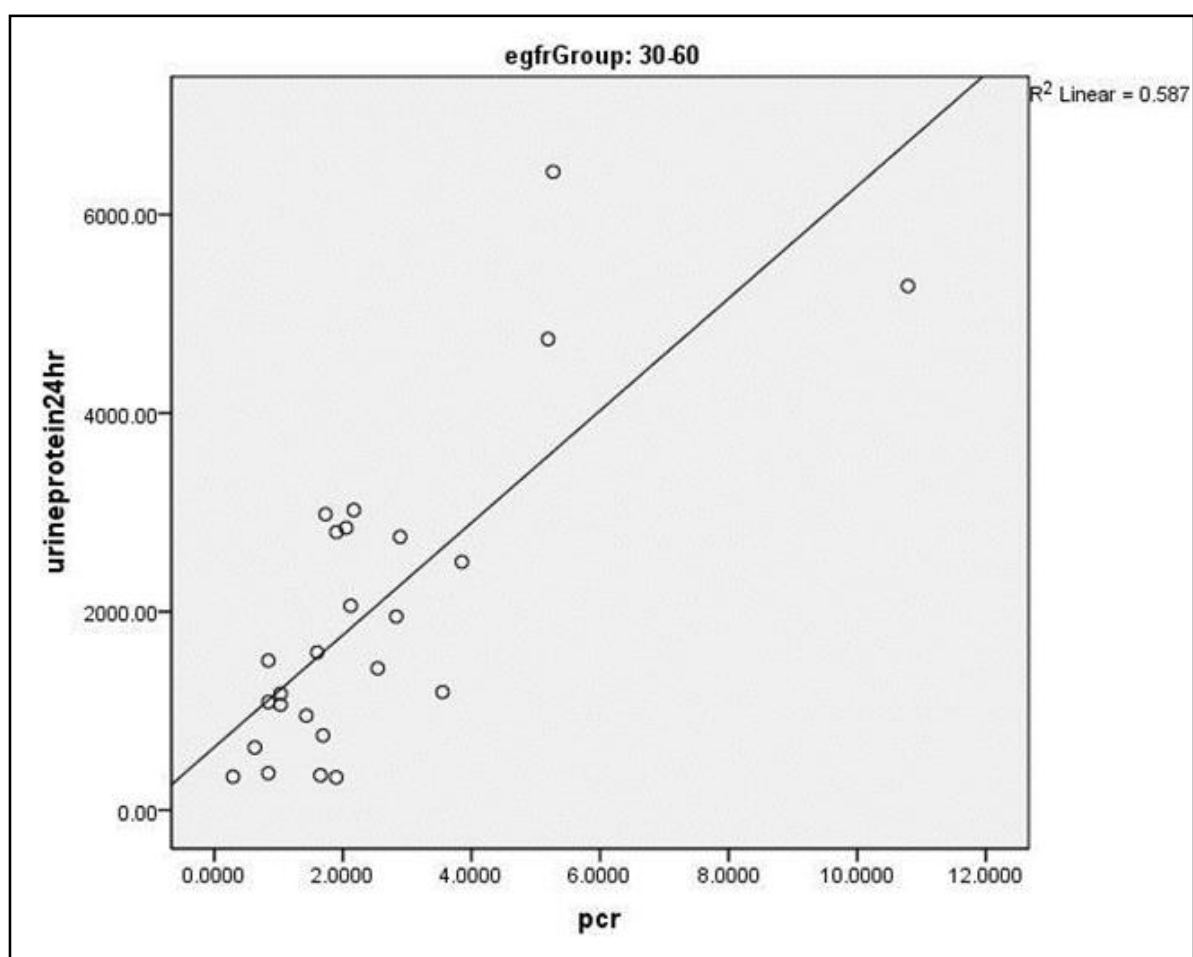

Correlation coefficient (r): 0.725 P value: $<0.001$

Fig 4: Correlation between urine PCR and $24 \mathrm{hr}$ urine protein (eGFR 30-60) 


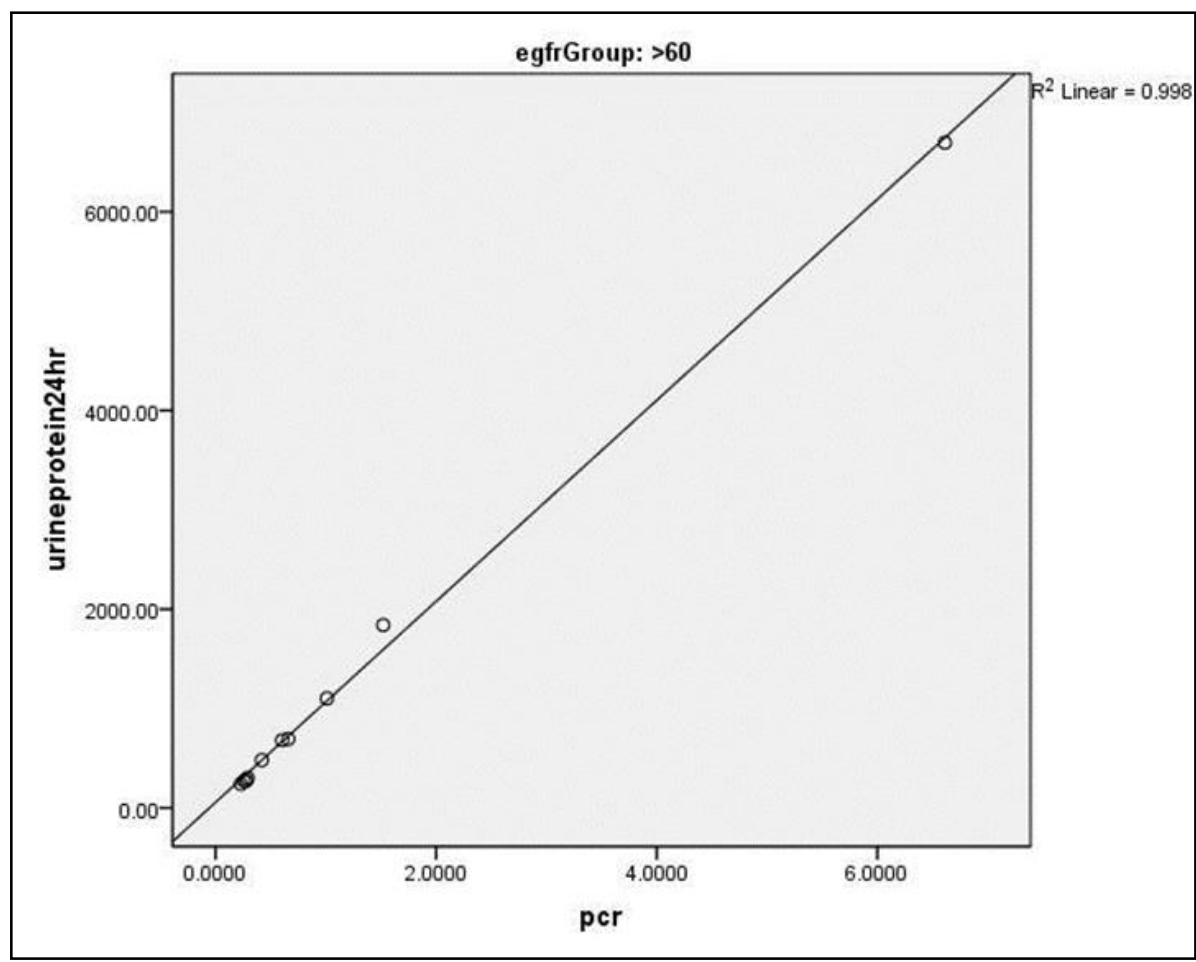

Fig 5: Correlation between urine PCR and $24 \mathrm{hr}$ urine protein (eGFR >60)

There was a significant and positive correlation between urine PCR and $24 \mathrm{hr}$ urine protein at all levels of eGFR. The maximum correlation was seen in the eGFR $>60$ group. $(r=$ 0.99 P value: $<0.001$ )

Table 3: Correlation between urine PCR and $24 \mathrm{hr}$ urine protein

\begin{tabular}{|c|c|c|}
\hline Proteinuria(mg/24hr) & Correlation coefficient(r) & P value \\
\hline$<300$ & 0.93 & $<0.001$ \\
\hline $300-3500$ & 0.632 & $<0.001$ \\
\hline$>3500$ & 0.783 & $<0.001$ \\
\hline
\end{tabular}

There was a significant positive correlation between urine PCR and $24 \mathrm{hr}$ urine protein at different levels of proteinuria. The Maximum correlation was seen in the proteinuria group $<300$.

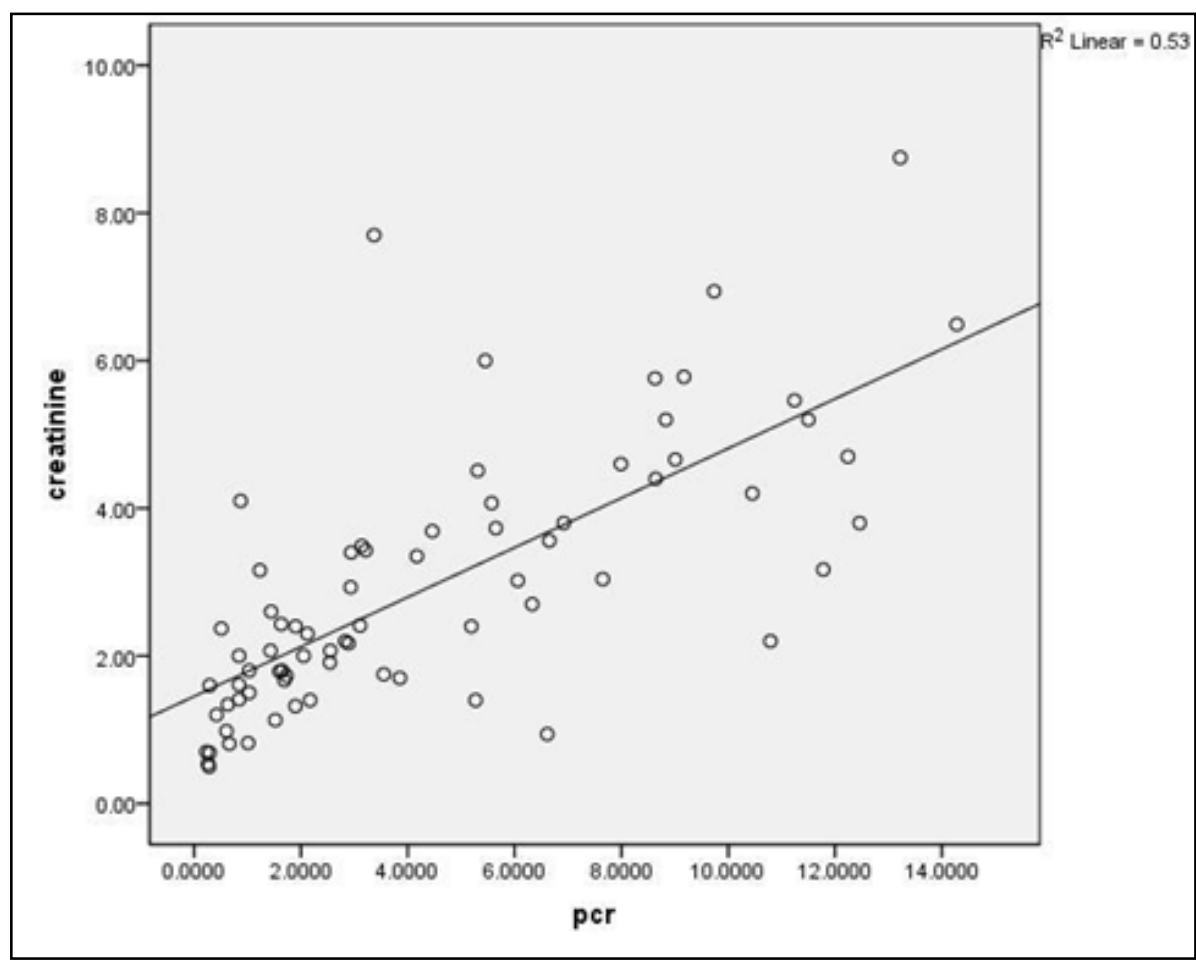

Fig 6: Correlation between urine PCR and serum creatinine (mg/dL) 
A significant positive correlation was found between urine PCR and serum creatinine in our study $(\mathrm{r}=0.774, \mathrm{P}$ value $<0.001)$.

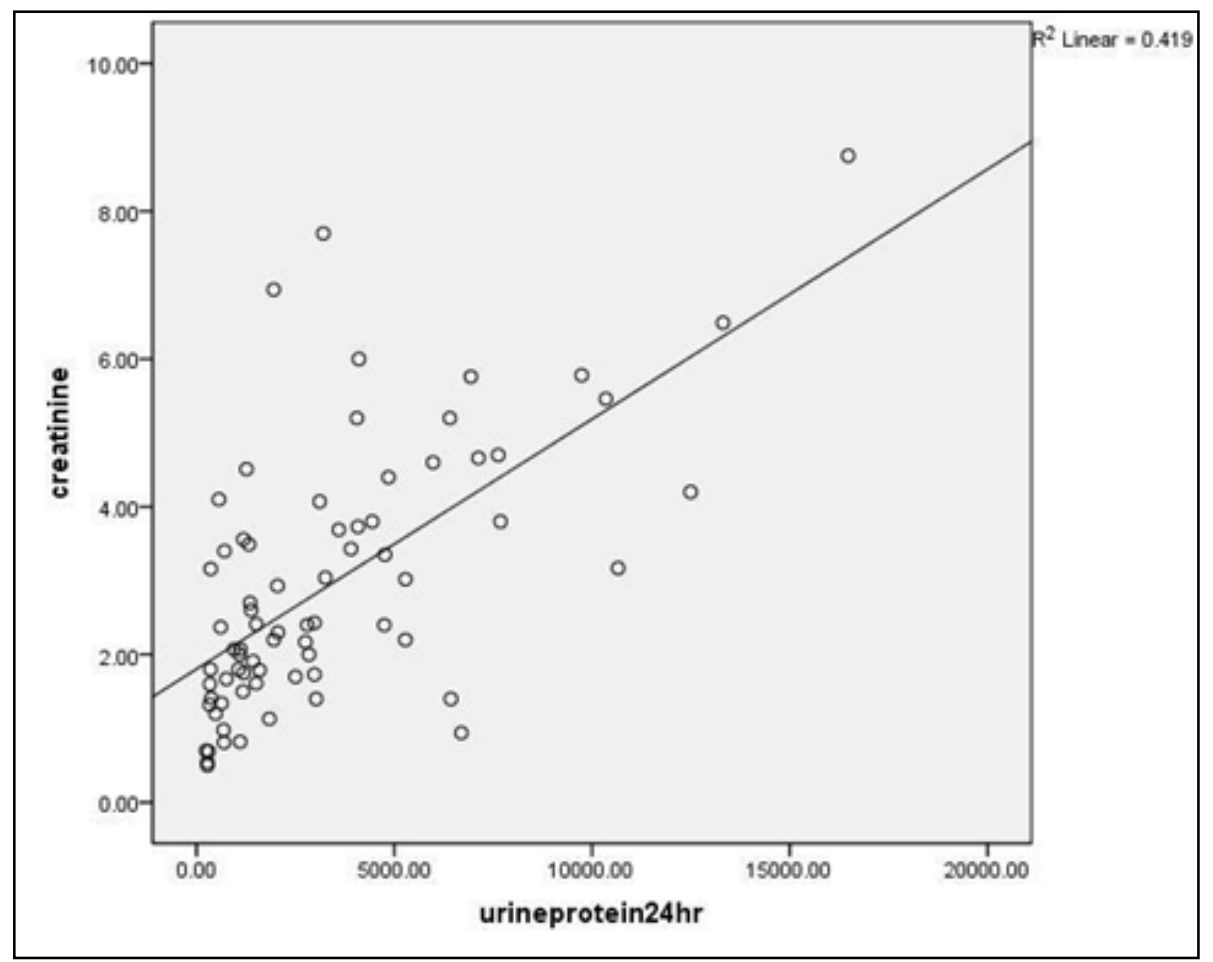

Fig 7: Correlation between $24 \mathrm{hr}$ urine protein and serum creatinine

There was a significant positive correlation between serum creatinine and $24 \mathrm{hr}$ urine protein in our study population. ( $\mathrm{r}$ $=0.656, \mathrm{p}$ value <0.001) There was no significant correlation between urine PCR and HBA1C levels. ( $\mathrm{r}=$ $0.076, \mathrm{p}$ value 0.52 ).

In our study, no significant correlation was found between urine PCR and duration of diabetes. $(\mathrm{r}=0.154$, $\mathrm{p}$ value $=$ 0.196)

\section{Discussion}

Diabetes specific renal disease (Diabetic nephropathy) develops in about one-third of all people with Type 1 or Type 2 diabetes and it contributes to about $30 \%$ of endstage renal disease (ESRD).Early identification of patients at high risk for diabetic nephropathy (DN) is important to intensify the treatment and modify associated risk factors. Proteinuria is an independent risk factor for renal diseases and a predictor of end-stage renal disease (ESRD). Measurement of protein excretion in a $24 \mathrm{hr}$ urine collection is the gold standard for the quantitative evaluation of proteinuria in diabetes. An alternative method for quantitative evaluation of proteinuria is a measurement of protein to creatinine ratio in a spot urine sample which provides a convenient method to assess protein excretion. 73 patients with type 2 diabetes mellitus and proteinuria were studied. The age of the patients studied ranged from 30 years to 80 years. The mean age of the patients was $51.9+/-$ 10.4 yrs. The mean age of female and male patients was $51.2+/-10.4$ yrs and $52.37+/-10.5$ respectively. The maximum number of patients was noted in the age group 41-50 years i.e., $26(35.1 \%)$ and least in the age group 20-30 years i.e., $1(1.35 \%)$.

Of the 73 patients studied, $49(67.1 \%)$ patients were males and $24(32.9 \%)$ patients were females. Male to female ratio is $2.04: 1$

In our study, out of the 73 patients with proteinuria, 25 patients $(34.25 \%)$ had nephrotic range proteinuria (>3.5gms/24 hours) and 48 patients (65.75\%) had proteinuria of less than $3.5 \mathrm{gms} / 24$ hours. Stoycheff $\mathrm{N}$ et al., in their study of 1,467 participants with diabetic kidney disease, $641(44 \%)$ had urine total protein level of $3.5 \mathrm{~g} / \mathrm{d}$ or greater ${ }^{[4]}$.

Nelson et al. selected 364 Pima Indians aged 35 years older with type 2 diabetes and proteinuria ${ }^{[5]}$. They found out that the incidence of ESRD attributed to diabetic nephropathy increased from 0 cases / 1000 person-years at $0-5$ years to 40.8 cases/ 1000 person-years at greater than or equal to 20 years duration of diabetes. Longer the duration of diabetes, the higher the frequency of diabetic nephropathy. The mean duration of diabetes in our study was $9.24+/-6.1$ yrs. The majority of patients had a duration of diabetes between 5 to 10 yrs - 38 patients $(52.05 \%)$.

Several studies have compared Urine PCR to $24 \mathrm{hr}$ urine estimation in the screening and evaluation of diabetic nephropathy. A good correlation between urine PCR and 24 hr urine protein has been demonstrated in patients with diabetic nephropathy. Biradar BS et al., in a study of 42 diabetic patients has found a positive correlation between 24 hours of urinary protein and spot urine PCR $(\mathrm{r}=0.925){ }^{6}$ Yadav BK et al. have also shown similar results $(\mathrm{r}=0.892)$ [7]. Ruggenenti et al. in his studies concluded that the 24 hours urine protein can be directly predicted from a random urine specimen by estimating the Protein-Creatinine ratio. There was a significant positive correlation between urine PCR and $24 \mathrm{hr}$ urine protein in our study $(\mathrm{r}=0.87 p<0.001)$ ${ }^{[8]}$. In a study on 46 patients by Ginsberg et al., an excellent correlation between 24-hour urine protein and the protein/creatinine ratio in a single urine sample was found. ${ }^{9}$ There was good correlation between urine PCR and $24 \mathrm{hr}$ urine protein at all levels of GFR in our study. The correlation in different levels of GFR were: (0-15) group: $r$ $=0.784, \mathrm{p}=<0.001,(15-30)$ group: $\mathrm{r}=0.756, \mathrm{p}=<0.001$, (30-60) group: $\mathrm{r}=0.725, \mathrm{p}=<0.001,>60$ group: $\mathrm{r}=0.99, \mathrm{p}$ 
$=<0.001$. Maximum correlation was seen in the GFR >60 group. High correlation coefficients $(\mathrm{r}=0.91,0.95$ and 0.98$)$ were observed in patients with normal, reduced and severely reduced renal function in a study done by Antunes et al. ${ }^{[10]}$. A study done by Absar A et al. showed that correlation between $24 \mathrm{hr}$ urine protein and urine PCR was significant at different levels of GFR, confirming that the ratio can be used instead of $24 \mathrm{hr}$ urine protein However, the result in GFR $<15 \mathrm{ml} / \mathrm{min}$ was not very convincing ${ }^{[10]}$. Morales JV et al. in his study showed that morning urine PCR had good sensitivity and specificity even in patients with reduced renal function ${ }^{[11]}$.

A good correlation was observed between spot urine protein/creatinine ratio and $24 \mathrm{hr}$ urine total protein excretion in different proteinuria ranges. The correlation in different levels of proteinuria were: $<300 \mathrm{mg}(\mathrm{r}=0.93, P<0.001)$, 300-3500 $\mathrm{mg}(\mathrm{r}=0.632, P<0.001)$ and 3,500 $\mathrm{mg}(\mathrm{r}=0.783, \mathrm{P}$ $<0.001)$. Maximum correlation was seen in the proteinuria group <300. A study done by Agarwal A125showed highly statistically correlation between $24 \mathrm{hr}$ urine protein and urine PCR at all levels of proteinuria. According to a study by Montero $\mathrm{N}$ et al. ${ }^{[12]}$, a strong correlation was observed between spot urine protein/creatinine ratio and 24-h urine total protein excretion in proteinuria levels from $300 \mathrm{mg} /$ day to $3,499 \mathrm{mg} /$ day. A lower correlation was maintained in $24-$ $\mathrm{h}$ urine total protein $<300 \mathrm{mg}$ and nephrotic range proteinuria. Mohan et al. studied the correlation between spot urine protein creatinine ratio and 24 hours urine protein in type 2 Diabetes. ${ }^{13}$ The positive correlation was good but was less with an increasing degree of proteinuria.

A significant positive correlation was found between urine PCR and serum creatinine in our study $(r=0.774$, P-value $<0.001)$. Similar good correlation was found between $24 \mathrm{hr}$ urine protein and creatinine $(r=0.656$, $\mathrm{p}$-value $<0.001)$ also. Studies have shown that proteinuria (assessed by urine PCR and $24 \mathrm{hr}$ urine protein) correlated well with creatinine levels. In the Ramipril Efficacy In Nephropathy (REIN) trial urinary protein excretion was found to be correlated significantly with GFR decline. ${ }^{14}$

\section{Conclusion}

In our study, no significant correlation was found between urine PCR and the duration of diabetes. Since the onset of type 1 diabetes is readily identifiable and the onset of type 2 diabetes is not, patients newly diagnosed with type 2 diabetes may present with advanced diabetic nephropathy. So the duration of diabetes may not correlate with the degree of proteinuria in type 2 diabetes mellitus. No statistically significant correlation was found between HBA1C levels and degree of proteinuria in our study. A significant positive correlation was found between $24 \mathrm{hr}$ urine protein and urine PCR at different levels of GFR and at different ranges of proteinuria. So urine protein creatinine ratio can be used as a faster diagnostic substitute for $24 \mathrm{hr}$ urine protein estimation in the screening and evaluation of diabetic nephropathy.

\section{References}

1. Price CP, Newall RG, Boyd JC. Use of protein: creatinine ratio measurements on random urine samples for prediction of significant proteinuria: a systematic review. Clin Chem 2005;51(9):1577-86.

2. Methven S, MacGregor MS, Traynor JP, O'Reilly DJ, Deighan CI. Assessing proteinuria in chronic kidney disease: protein-creatinine ratio versus albumincreatinine ratio.Nephrol Dial Transplant 2010;25(9):2991-6.

3. Refaat HA, Mady GE, Abdel Ghany MM, Abou Seif KH, El Hadidi ES, Elshahawy Y, et al. Correlation between tumor necrosis factor alpha and proteinuria in type -2 diabetic patients. Arab Journal of Nephrology and Transplantation 2010;3(1):33-8.

4. Stoycheff N, Stevens LA, Schmid CH, Tighiouart H, Lewis J, Atkins RC, et al. Nephrotic syndrome in diabetic kidney disease: an evaluation and update of the definition Am J Kidney Dis 2009;54(5):840-9.

5. Nelson RG, Knowler WC, Mc Cane DR, Sievers ML, Pettitt DJ. Determinants of ESRD in Pima Indians with type 2 DM \& proteinuria. Diabetologia 1993;36(10):1087-93.

6. Biradar SB, Kallaganad GS, Rangappa M, Kashinakunti SV, Retnakaran R. Correlation of spot urine protein-creatinine ratio with 24-hour urinary protein in type 2 diabetes mellitus patients: A cross sectional study. J Res Med Sci 2011;16(5):634-639.

7. Yadav BK, Adhikari S, Gyawali P, Shrestha R, Poudel $\mathrm{B}$, Khanal $\mathrm{M}$, et al. Use of protein: creatinine ratio in a random spot urine sample for predicting significant proteinuria in diabetes mellitus. Nepal Med Coll J 2010;12(2):100-5

8. Ginsberg JM, Chang BS, Matarese RA, Garella S. Use of single voided urine samples to estimate quantitative proteinuria. N. Engl. J. Med 1983;309:1543-1546

9. Antunes VV, Veronese FJ, Morales JV. Diagnostic accuracy of the protein/creatinine ratio in urine samples to estimate $24-\mathrm{h}$ proteinuria in patients with primary glomerulopathies: a longitudinal study. Nephrol Dial Transplant 2008;23:2242-6

10. Absar A, Naila A, Sonia Y, Waqar K, Diamond M, Iffat Y, et al. Spot Urine Protein: Creatinine Ratio versus 24 Hour Urine Protein at Various Levels of GFR patients referred to a Tertiary Care Hospital of Pakistan J Pak Med Assoc

11. Montero N, Soler MJ, Pascual MJ, Barrios C, Márquez E, Rodríguez E, et al. Berrada A, Riera M, Coca L, Orfila MA, Pascual J Correlation between the protein/creatinine ratio in spot urine and 24-hour urine protein Nefrologia 2012;32(4):494-50

12. Mohan V, Viswanathan M. Estimation of 24 hours proteinuria: comparison of two methods. Journal Diab Ass Ind 1987;27:73-75.

13. Trevisan R, Vedovato M, Mazzon C, Coracina A, Iori $\mathrm{E}$, Tiengo A, et al. Concomitance of diabetic retinopathy and proteinuria accelerates the rate of decline of kidney function in type 2 diabetic patients Diabetes Care 2002;25(11):2026-31 